\title{
Wielokadencyjność bez afiliacji partyjnej? Spostrzeżenia po reelekcjach „wiecznych prezydentów” w 2014 r.
}

\begin{abstract}
Streszczenie: Od 2002 r. prezydenci miast są wybierani co 4 lata w wyborach bezpośrednich. W 30 miastach na prawach powiatu w latach 2002-2010 wybierano na prezydentów te same osoby. Określa się ich mianem ,wiecznych prezydentów” (wielokadencyjni prezydenci). W 2014 r. trzech $\mathrm{z}$ nich zrezygnowało $\mathrm{z}$ walki o reelekcje, a dziesięciu przegrało wybory, a zatem siedemnastu kolejny raz wygrało wybory. Ich zwycięstwa są punktem wyjścia do określenia pozycji partii politycznych i komitetów pozapartyjnych na lokalnych scenach politycznych. Przyjęto bowiem założenie, że pozycja partii politycznej jest mocna, o ile dotychczasowy wielokadencyjny włodarz miasta skutecznie ubiega się o reelekcję, formalnie ją reprezentując. A contrario - jeśli inkumbent w walce o reelekcję wybiera start z komitetu pozapartyjnego (komitet wyborczy wyborców albo komitet wyborczy organizacji pozarządowej) to świadczy to o słabszej pozycji partii politycznej w danym mieście.

Analiza pokazała, że w 2014 r. większość ,wiecznych prezydentów” dokonała reelekcji, startując w wyborach jako reprezentanci komitetów pozapartyjnych. Tylko w dwóch przypadkach (Gdańsk, Świnoujście) fotele włodarzy miast zostały zajęte przez partyjnych inkumbentów.
\end{abstract}

Slowa kluczowe: polityka lokalna, wybory prezydentów miast, wielokadencyjni prezydenci, władza lokalna

$\mathbf{W}$ ybory są czynnikiem determinującym rozwój i funkcjonowanie demokracji. Szczególnie istotne jest dbanie o ich cykliczne przeprowadzanie oraz sprawne funkcjonowanie wybieranych w ich konsekwencji organów przedstawicielskich. Te wybierane na poziomie lokalnym są zaś warunkiem sine qua non dobrze działającej samorządności. Klasyk teorii demokracji Giovanni Sartori, zauważył bowiem, iż definiowanie samorządności nie jest trudne: „Łatwo zdefiniować pojęciowo samorząd. Polega on na tym, że rządzimy sami sobą. Kiedy jednak stosujemy to pojęcie do realnego świata, musi być określone empirycznie. Jest to niezbędne do stwierdzenia natężenia samorządu, tzn. czy i w jakim stopniu słowo to ma zastosowanie (do swoich punktów odniesienia) w silnym albo słabym sensie. Dla uproszczenia wywodu stwierdzę, że samorząd ma natężenie maksymalne, albo tym większe, im bardziej rządzenie odpowiada temu, co wyraz ten dosłownie oznacza" (Sartori, 1994, s. 89).

Z kolei Andrzej Chodubski pisał, iż ,istota samorządu terytorialnego sprowadza się do współrządzenia państwa ze społeczeństwem", a współczesne zadania samorządu to m.in. pobudzanie aktywności społecznej, unowocześnianie państwa i jego organizowanie na płaszczyźnie gospodarczej (Chodubski, 2004, s. 57). Już na podstawie powyżej przywołanych spostrzeżeń widać zatem, iż istotą samorządności jest, z jednej strony realne zaangażowanie w nią danej, współzamieszkującej określone terytorium społecz- 
ności lokalnej, a z drugiej strony - współdziałanie tejże społeczności z instytucjami państwowymi. Co więcej, jak zauważono w literaturze przedmiotu, instytucje samorządu terytorialnego mają istotny wpływ na zwiększenie poziomu demokratyzacji, a zaangażowanie się w ich działanie obywateli prowadzi do reprezentowania woli większości (Wojtasik, 2012, s. 235; Sobociński, 1995, s. 23).

Ponadto, jak twierdził Sartori, wymóg pełnego uczestnictwa w demokracji bezpośredniej prowadzi do swoistego paradoksu - „,bezpośredni, rzeczywisty samorząd jest nie do pomyślenia, ponieważ wymaga on faktycznej obecności wszystkich zainteresowanych”, a „im większa jest liczba uczestników, tym mniej efektywne staje się ich uczestnictwo, aż wreszcie zanika" (Sartori, 1994, s. 347-48; Chodubski, 2006, s. 13-14).

Prostym rozwiązaniem dla powyżej wyrażonych niedoskonałości samorządności jest przeprowadzanie wyborów lokalnych, w których umożliwia się start komitetom wyborczym reprezentującym różne grupy obywateli - (komitety wyborcze wyborców - KWW, komitety wyborcze organizacji - KWO). Generalnie, praktyka działania demokracji na poziomie lokalnym wskazuje, iż do reprezentowania mieszkańców danej gminy czy miasta zawsze gotowe są dwa rodzaje komitetów: te utworzone na bazie struktur partii politycznych (przede wszystkim tych parlamentarnych) lub organizacji społecznych oraz zorganizowane w oparciu o lokalne, pozapartyjne inicjatywy obywatelskie (Kodeks wyborczy, art. 399). Waldemar Wojtasik dodaje, iż „poziom lokalny sprzyja osłabieniu w głosowaniu znaczenia czynników ideologicznego i partyjnego. Wyborcy częściej oddają swoje głosy na kandydatów niezależnych bądź z innych partii, niż wynikałoby to z ich naturalnych preferencji ideologicznych" (Wojtasik, 2013). Jednak, jak wynika z badań opublikowanych w 2013 r. elektoraty poszczególnych partii politycznych zajmują stanowiska ambiwalentne w kwestii sympatii dla komitetów lokalnych (Kolczyński, Faracik-Nowak, 2013). Specyficznym przypadkiem funkcjonowania samorządu terytorialnego są miasta na prawach powiatu (tzw. powiaty grodzkie), a zwłaszcza te, w których mieszkańcy tej samej osobie powierzają fotel prezydenta kilka razy w następujących po sobie elekcjach (tzw. „wieczni prezydenci”). W pierwszych trzech wyborach, w których wybierano bezpośrednio włodarzy miast (lata 2002, 2006, 2010) tym samym osobom powierzano fotel prezydenta w 30 miastach. Byli to: Andrzej Czapski, (Biała Podlaska), Jacek Krywult (Bielsko-Biała), Paweł Adamowicz (Gdańsk), Wojciech Szczurek (Gdynia), Zbigniew Frankiewicz (Gliwice), Tadeusz Jędrzejczak (Gorzów Wielkopolski), Marian Janecki (Jastrzębie-Zdrój), Paweł Silbert (Jaworzno), Janusz Pęcherz (Kalisz), Piotr Uszok (Katowice), Wojciech Lubawski (Kielce), Jacek Majchrowski (Kraków), Piotr Przytocki (Krosno), Tadeusz Krzakowski (Legnica), Tomasz Malepszy (Leszno), Ryszard Zembaczyński (Opole), Stanisław Korfanty (Piekary Śląskie), Ryszard Grobelny (Poznań), Robert Choma (Przemyśl), Adam Fudali (Rybnik), Tadeusz Ferenc (Rzeszów), Maciej Kobyliński (Słupsk), Jacek Karnowski (Sopot), Kazimierz Górski (Sosnowiec), Janusz Żmurkiewicz (Świnoujście), Michał Zaleski (Toruń), Andrzej Dziuba (Tychy), Rafał Dutkiewicz (Wrocław), Marcin Zamoyski (Zamość), Waldemar Socha (Żory) (szerzej: Drzonek, 2013).

Celem niniejszych rozważań jest, sprawdzenie, które komitety wyborcze - rejestrowane formalnie przez partie polityczne, czy raczej te o charakterze lokalnym, pozapartyjnym - w 2014 r. posiadały większe znaczenie w dokonywaniu reelekcji we wspomnianych wyżej miastach. 
Podstawowa, stawiana na początku teza jest następująca: partie polityczne odgrywają mniejszą rolę w miastach, w których rządzą wielokadencyjni prezydenci. Aby sprawdzić pozycję partii i komitetów pozapartyjnych zasadne jest znalezienie odpowiedzi na pytanie czy w przypadku reelekcji ,wiecznych prezydentów” w 2014 r. dominowały w nich komitety lokalne, czy też te o charakterze partyjnym. Odpowiedź na nie będzie poszukiwana przy zastosowaniu metody komparatystycznej - miasta, w których reelekcji dokonali urzędujący w nich wcześniej ,wieczni prezydenci” zostaną zestawione z reprezentowanym przez nich typem komitetów wyborczych. Przyjęto bowiem założenie, że pozycja partii politycznej jest silna, o ile dotychczasowy wielokadencyjny włodarz miasta skutecznie ubiega się o reelekcję, formalnie ją reprezentując. A contrario - jeśli inkumbent w walce o reelekcję wybiera start z komitetu lokalnego (KWW lub KWO), to świadczy to o słabszej pozycji politycznej partii w danym mieście.

\section{Zdobywanie władzy na poziomie lokalnym - partie i komitety pozapartyjne}

Celem wyborów w systemie demokratycznym jest zdobycie władzy przez reprezentantów ogółu obywateli, w wyniku którego następuje podział na rządzących i rządzonych. We współczesnych demokracjach przejmowanie władzy odbywa się za pośrednictwem partii. Na poziomie ogólnopaństwowym, w wyborach parlamentarnych, właśnie stronnictwa polityczne są głównymi, a w praktyce funkcjonowania niektórych systemów politycznych - jedynymi organizacjami, które posiadają realne szanse na przejęcie organów władzy państwowej. Podstawową dominantą definicji partii politycznych jest element „dążenia do zdobycia lub utrzymania władzy” (Chmaj, Sokół, Żmigrodzki, 2001, s. 17; Heywood, 2006, s. 306; Bankowicz, 2006, s. 130; Duverger, 1973; Sartori, 1976, s. 63, za: Bankowicz, 2006).

W przypadku elekcji odbywających się na poziomie lokalnym, partie polityczne, co oczywiste, posiadają taki sam cel działania - dążenie do zdobycia lub utrzymania władzy politycznej. Podobnie, organizacje społeczne biorące udział w rywalizacji wyborczej do organów samorządu terytorialnego, czy też ad hoc tworzone lokalne komitety wyborcze mają ten sam cel - udział w sprawowaniu władzy lokalnej. Pomimo tej pozornej zbieżności celów stronnictw politycznych i aktorów lokalnych, można dostrzec pewną istotną różnicę. Otóż, partie polityczne z reguły traktują udział w rywalizacji wyborczej na poziomie lokalnym jako cel i zarazem środek do celu długofalowego: zdobywanie miejsc w strukturach władzy lokalnej jest bowiem środkiem, który ma pozwolić na zdobycie lepszej pozycji do wzięcia udziału w rywalizacji o przejmowanie struktur władzy centralnej.

Takich dalekosiężnych celów z reguły nie stawiają sobie pozapartyjni aktorzy występujący na lokalnych scenach politycznych. Lokalni uczestnicy elekcji samorządowych rywalizują w zasadzie wyłącznie o udział li tylko w lokalnych strukturach władzy - w praktyce nie zdarza się bowiem, aby pozapartyjne, lokalne inicjatywy polityczne aspirowały do udziału w centralnych organach władzy państwowej ${ }^{1}$. W li-

${ }^{1}$ Choć są pewne precedensy: w 2011 roku (po sukcesie ugrupowania prezydenta Wrocławia Rafała Dutkiewicza - Dolny Śląsk XXI - w wyborach do sejmiku dolnośląskiego w 2010 roku) zawiązano inicjatywę Unia Prezydentów - Obywatele do Senatu. W wyborach z 2011 roku udało się jednak zdo- 
teraturze można też spotkać opinie potwierdzające taktyczne, a nie strategiczne traktowanie przez partie polityczne rywalizacji na poziomie lokalnym: budowanie silnej pozycji w okręgach wyborczych do parlamentu, poszerzanie własnych zasobów władzy (klientelizm i zajmowanie stanowisk przez działaczy partyjnych w tzw. terenie), wzmacnianie interakcji z wyborcami między elekcjami parlamentarnymi (Matyja, 2013, s. 368-369).

Tak więc, uogólniając można dojść do następującej konstatacji: celem startu w wyborach lokalnych ugrupowań o charakterze pozapartyjnym jest zdobycie władzy w strukturach samorządu terytorialnego, a celem partii politycznych jest, poprzez przejęcie stanowisk w organach samorządowych, zajęcie lepszych pozycji wyjściowych do późniejszej rywalizacji o władzę w centralnych organach państwowych. Szczególnym aspektem rywalizacji lokalnej w kontekście walki o stanowiska we władzach centralnych jest zdobywanie stanowisk w samorządowej egzekutywie - wójtów, burmistrzów i prezydentów.

Z uwagi na zazwyczaj większy potencjał, wielkość demograficzną i silniejszą pozycję władczą (kompetencje wójta i starosty) szczególnie ważne są fotele prezydentów miast na prawach powiatu. Rywalizacja o nie ma dodatkowy walor z punktu widzenia interesów partii politycznych - jest silnie spersonalizowana, a to partie polityczne mające na co dzień większe możliwości promowania swoich działaczy w mediach ogólnokrajowych i lokalnych - mogą na tym skorzystać. Jak bowiem zauważał A. Antoszewski, elekcje na poziomie samorządu terytorialnego posiadają swoje specyficzne determinanty. Obok wspomnianych już atrybutów - mocnej personalizacji oraz w znaczącej części pozapartyjnego charakteru występujących w niej aktorów - dostrzega się także, w relacji do wyborów parlamentarnych niski poziom alternacji. Ten atrybut rywalizacji na poziomie lokalnym w konsekwencji jest bardzo wyraźnie dostrzegalny. Zarówno w organach uchwałodawczych samorządów terytorialnych, jak i w strukturach lokalnych egzekutyw, nierzadko przez wiele kadencji zasiadają te same osoby, które - skądinąd będąc przecież wybieranymi wedle reguł demokratycznych - przez wiele lat (w wielu wypadkach powyżej 10) zajmują stanowiska radnych, wójtów, burmistrzów i prezydentów. Silna pozycja ugrupowań konstytuujących lokalne sceny polityczne (albo partyjnych albo pozapartyjnych) może z kolei prowadzić do ich dominacji przejawiającej się w posiadaniu bezwzględnej liczby miejsc w radach gmin i miast (Antoszewski, 2012, s. 207-217).

\section{Wielokadencyjność prezydentów miast-powiatów grodzkich}

W nomenklaturze samorządowej III Rzeczpospolitej szefa egzekutywy miasta określa się mianem „burmistrza” lub „prezydenta”. W Polsce sto siedem gmin miejskich posiada prezydentów, a w pozostałych miastach na czele ich magistratów zasiadają burmistrzo-

być tylko jedno miejsce senatorskie, które otrzymał Jarosław Obremski (wcześniej pełniący funkcję wiceprezydenta Wrocławia). Zdarzają się także przypadki kiedy lokalne inicjatywy (po sukcesach na poziomie gmin czy miast) rywalizują o stanowiska radnych w sejmikach. Poza wspomnianym przykładem z Dolnego Śląska można też wspomnieć o inicjatywie KWW „Bezpartyjni” (Szczecin i Pomorze Zachodnie w 2014 roku). 
wie. Trzeba wyraźnie stwierdzić, że de facto nie ma różnic kompetencyjnych pomiędzy prezydentami i burmistrzami. Jednakże wśród wspomnianych 107 miast, 66 posiada charakter tzw. powiatów grodzkich. O prezydentach tychże miast (na prawach powiatów) można jednak powiedzieć, że mają kompetencje takie same jak te posiadane przez wszystkich burmistrzów (i wójtów w gminach). Dodatkowo jednakże prezydenci miastpowiatów posiadają takie uprawnienia, jak te będące udziałem starostów w powiatach ziemskich. Zatem wyróżnić można w Polsce dwie kategorie prezydentów miast: włodarzy zasiadających w 66. miastach-powiatach grodzkich posiadających zarazem większe uprawnienia oraz włodarzy 41 miast, w których stanowisko szefa lokalnej egzekutywy zwyczajowo (bądź ze względów historycznych) określa się mianem „prezydenta”, choć pod względem posiadanych kompetencji nie różni się ono od burmistrza w pozostałych miastach i wójta $\mathrm{w}$ gminach ${ }^{2}$.

Warto też wspomnieć, że miasta na prawach powiatów grodzkich charakteryzują się także istotnym zróżnicowaniem politycznym, które, jak pokazywała dotychczasowa praktyka wyborcza lat 2002-2010, nie zawsze pokrywały się z utartymi schematami struktury preferencji politycznych obserwowanych w elekcjach parlamentarnych (Matyja, 2014).

Z kolei określenie „wielokadencyjny prezydent” używane jest jako synonim pojawiającego się w literaturze terminu ,wieczny prezydent” (Drzonek, 2013a; idem, 2013b; idem, 2013c). Termin ten można interpretować na dwa sposoby. Po pierwsze, można za „wiecznego prezydenta” uznawać takiego włodarza miasta, którego wybierano we wszystkich dotychczasowych wyborach bezpośrednich (a więc w latach 2002, 2006, 2010 i 2014). Druga interpretacja ma nieco węższy charakter - w tym przypadku wielokadencyjność włodarza pojawia się w przypadku, kiedy w bezpośredniej elekcji mieszkańcy powierzyli mu fotel prezydenta miasta kolejno w co najmniej trzech następujących po sobie elekcjach. Przyjęcie pierwszej, bardziej rygorystycznej interpretacji pojęcia „wieczny prezydent” z jednej strony pozwala na wyodrębnienie niezwykle wyrazistych przypadków wielokadencyjności (prezydenci „od zawsze wybierani” przez mieszkańców). $Z$ drugiej jednakże strony taka interpretacja w przyszłości doprowadzi przecież do sytuacji, że zbiór wielokadencyjnych prezydentów będzie pusty - każda osoba pełniąca tę funkcję po pewnym okresie przestanie ją w końcu pełnić.

Ponieważ po wyborach 2014 r. grupa „wiecznych prezydentów” jest stosunkowo liczna (obejmuje 17 włodarzy) w dalszych rozważaniach analizie poddano właśnie włodarzy, którzy wygrywali elekcje bezpośrednie w latach 2002-2014. Dodatkowym ograniczeniem analizy, jak wcześniej już zasygnalizowano, jest zastosowanie jej do powiatów grodzkich.

2 Na marginesie warto zauważyć, że miasta na prawach powiatów posiadają duże dysproporcje pomiędzy sobą pod względem demograficznym. Przykładowo Krosno, Sopot czy Świnoujście mają po ok. 40 tys. mieszkańców, Opole, Gorzów Wlkp. czy Tychy - niespełna 130 tys., Gdynia, Sosnowiec i Torun - ponad 200 tys., Poznań, Kraków i Wrocław - ponad 0,5 mln, a stołeczna Warszawa - ok. $1,7 \mathrm{mln}$. Paradoks wynikający z tej sytuacji polega na tym, że władze wszystkich powiatów grodzkich mają takie same kompetencje, podczas, gdy burmistrzowie miast niebędących powiatami grodzkimi, ale zarazem będącymi liczebnie większymi od najmniejszych powiatów grodzkich posiadają przecież uprawnienia nieco uboższe. 


\section{Pozycja partii i ugrupowań pozapartyjnych po wyborach z 2014 r.}

W 2014 r. odbyły się wybory samorządowe w 65 powiatach grodzkich ${ }^{3}-\mathrm{w}$ ich rezultacie okazało się, że spośród 30 prezydentów, którzy wygrywali wybory w trzech elekcjach lat 2002-2010 siedemnastu ponownie uzyskało mandat na kolejną kadencję, dziesięciu zostało pokonanych, a trzech nie ubiegało się o reelekcję. Wśród pokonanych w 2014 r. znaleźli się włodarze: Białej Podlaski (Andrzej Czapski), Gorzowa Wlkp. (Tadeusz Jędrzejczak), Jastrzębia-Zdroju (Marian Janecki), Kalisza (Janusz Pęcherz), Leszna (Tomasz Malepszy), Piekar Śląskich (Stanisław Korfanty), Poznania (Ryszard Grobelny), Rybnika (Adam Fudali), Sosnowca (Kazimierz Górski) i Zamościa (Marcin Zamoyski). O reelekcję nie ubiegali się natomiast włodarze Katowic (Piotr Uszok), Opola (Ryszard Zembaczyński) oraz Słupska (Maciej Kobyliński) ${ }^{4}$.

$\mathrm{Z}$ powodzeniem reelekcji dokonali natomiast włodarze następujących miast na prawach powiatów, którzy tym samym zdobyli władzę co najmniej ${ }^{5}$ na czwartą kadencję: Bielska-Białej (Jacek Krywult, KWW), Gdańska (Paweł Adamowicz, PO), Gdyni (Wojciech Szczurek, KWW), Gliwic (Zygmunt Frankiewicz, KWW), Jaworzna (Paweł Silbert, KWW), Kielc (Wojciech Lubawski, KWW), Krakowa (Jacek Majchrowski, KWW), Krosna (Piotr Przytocki, KWW), Legnicy (Tadeusz Krzakowski, KWW), Przemyśla (Robert Choma, KWW), Rzeszowa (Tadeusz Ferenc, KWW), Sopotu (Jacek Karnowski, KWW), Świnoujścia (Janusz Żmurkiewicz, SLD), Torunia (Michał Zaleski, KWW), Tych (Andrzej Dziuba, KWW), Wrocławia (Rafał Dutkiewicz, KWW), Żor (Waldemar Socha, KWW).

Jak się okazało, zdecydowana większość prezydentów spośród wyżej wymienionych zwyciężała bez oficjalnego poparcia partii politycznych. Jedynie w dwóch miastach - Gdańsku i Świnoujściu - ich prezydenci dokonali kolejnej reelekcji (P. Adamowicz - piątej, a J. Żmurkiewicz - czwartej) startując w wyborach prezydenckich jako oficjalni kandydaci partii politycznych. W przypadku włodarza Gdańska „partią prezydencką” okazywała się Platforma Obywatelska, a w sytuacji reelekcji włodarza stolicy Wyspy Uznam - Sojusz Lewicy Demokratycznej. Co więcej, należy podkreślić, że P. Adamowicz i J. Żmurkiewicz są wyłącznymi przypadkami „,wiecznych prezydentów”, w których prezydent miasta-powiatu grodzkiego zawsze zdobywał fotel włodarza reprezentując tę samą opcję partyjną w latach 2002, 2006, 2010 i $2014^{6}$.

Piętnastu pozostałych wielokadencyjnych prezydentów w 2014 r. skutecznie ubiegało się o reelekcję, reprezentując w wyborach komitety lokalne. Innymi słowy, włodarze z tej kategorii formalnie byli liderami komitetów wyborczych wyborców (KWW). Na

${ }^{3}$ Wybory w 66. mieście tej kategorii - Zielonej Górze - odbyły się później, bo 15 III $2015 \mathrm{r}$. W pierwszej turze wygrał je Janusz Kubicki, dotychczasowy prezydent miasta (od 2006 r.).

${ }^{4}$ Trzeba jednak odnotować, że P. Uszok podejmując decyzję o nie ubieganiu się o kolejną kadencję na fotelu prezydenta Katowic „namaścił” na swojego następcę Marcina Krupę, który wybory wygrał.

5 „Co najmniej”, ponieważ wśród 17 wielokadencyjnych prezydentów kilku z nich po raz pierwszy zasiadło na fotelach prezydenckich jeszcze przed 2002 r.: od 1993 - Zygmunt Frankiewicz, od 1998 - Paweł Adamowicz, Jacek Karnowski, Waldemar Socha, Wojciech Szczurek; od 2000 - Andrzej Dziuba.

${ }^{6}$ Zastrzegając jednakże, iż J. Żmurkiewicz był kandydatem SLD (lata 2002 i 2010) lub komitetów koalicyjnych, w których partia ta odgrywa rolę dominującą (2006 rok - KKW LiD; 2014 rok - KKW SLD Lewica Razem). 
pierwszy rzut oka, skoro tylko dwóch „wiecznych prezydentów” w 2014 r. posiadało korzenie partyjne, a 15 walczyło o prezydenturę na czele KWW, to wniosek o silniejszej pozycji tych drugich nasuwa się sam. W praktyce rywalizacji politycznej na poziomie lokalnym trzeba jednak uwzględnić, że wiele partii politycznych stosuje kamuflaż „lokalności" chcąc uczynić niewidocznym swoją partyjną istotę. Prowadzi to do konieczności wyodrębnienia tzw. aktorów niby-bezpartyjnych spośród części komitetów zarejestrowanych formalnie jako KWW (Gendźwiłł, 2010; Piasecki, 2007, s. 296-311; Hess, 2010, s. 157-158; Sobolewska-Myślik, 2008, s. 305-307). Co oczywiste, uznanie KWW za aktora niby-bezpartyjnego odbywa się na podstawie badań jakościowych i częściowo może mieć charakter subiektywny (Drzonek, 2014, s. 97-111). Wydaje się jednak, że w 2014 r. właśnie taki charakter miały komitety wyborcze zwycięskich prezydentów czterech miast: Kielc (W. Lubawski - KWW Porozumienie Samorządowe W. Lubawski), Legnicy (T. Krzakowski - KWW Tadeusza Krzakowskiego), Sopotu (J. Karnowski - KWW Platforma Sopocian Jacka Karnowskiego) oraz Wrocławia (R. Dutkiewicz - KWW Rafał Dutkiewicz z Platforma).

Za uznaniem powyższych komitetów za niby-bezpartyjne przemawia kilka argumentów. Prezydent Kielc, ubiegając się o reelekcję startował z KWW Porozumienie Samorządowe W. Lubawski, ale otrzymał poparcie PiS. Tym samym partia ta nie wystawiła własnego kandydata. Ponadto w rywalizacji o mandaty radnych Kielc, z list komitetu prezydenckiego startowali przedstawiciele innego ugrupowania politycznego - Polski Razem. W wyborach do sejmiku świętokrzyskiego na liście PiS znaleźli się z kolei działacze Porozumienia Samorządowego. Prezydent Legnicy, T. Krzakowski, jest członkiem SLD (w 2002 r. wygrał wybory oficjalnie startując z komitetu SLD), a partia ta nie wystawiła własnego pretendenta do prezydentury w 2014 r. Włodarz Sopotu w 2014 r. ubiegał się o reelekcję na czele KWW Platforma Sopocian Jacka Karnowskiego. Wspomniany komitet wyborczy może być uznany za klasyczny twór niby-bezpartyjny - już nazwa własna sugerowała jego konotacje partyjne. Ponadto w Sopocie PO nie tylko nie wystawiła własnego pretendenta do fotela prezydenta, ale również nie wystartowała samodzielnie w rywalizacji o mandaty radnych. Identyczna sytuacja miała miejsce we Wrocławiu - KWW Rafał Dutkiewicz z Platformą w czytelny sposób wskazywał powiązania z PO, a przedstawiciele tej partii startowali z list wspomnianego KWW do rady miasta.

\section{Wnioski}

Wyniki wyborów wielokadencyjnych prezydentów miast w 2014 r. potwierdziły hipotezę, zgodnie z którą partie polityczne posiadają słabszą pozycję na lokalnych scenach politycznych tych miast. Większość , wiecznych prezydentów” dokonała reelekcji startując w wyborach jako reprezentanci komitetów lokalnych (KWW). Tylko w dwóch przypadkach (Gdańsk, Świnoujście) fotele włodarzy miast zostały zajęte przez partyjnych inkumbentów. Co prawda w kilku przypadkach lokalność prezydentów była „,skażona niby-bezpartyjnością", ale chowanie się partii politycznych pod szyldami komitetów lokalnych potwierdza, a nie falsyfikuje powyższą tezę. Skoro bowiem partie polityczne uciekają się do stosowania praktyk niby-bezpartyjności, to oznacza to tyle tylko, że ko- 
mitety lokalne posiadają większą efektywność w przejmowaniu władzy lokalnej przez wiecznych prezydentów. Partie nie stosowałyby przecież tego typu działań, gdyby nie prowadziły one do zwiększenia prawdopodobieństwa przejęcia władzy przez popieranych przez nie inkumbentów.

\section{Bibliografia}

Antoszewski A. (2012), Partie polityczne $w$ rywalizacji o władze $w$ województwach $i$ wielkich miastach, w: Obywatel - instytucje - władza na przełomie XX i XXI wieku. Ksiega dedykowana Profesorowi Tadeuszowi Godlewskiemu, red. D. Karnowska, J. Nocoń, Wydawnictwo Adam Marszałek, Toruń.

Bankowicz M. (2006), Demokracja. Zasady, procedury, instytucje, Wydawnictwo Uniwersytetu Jagiellońskiego, Kraków.

Chmaj M., Sokół W., Żmigrodzki M. (2001), Teoria partii politycznych, Wydawnictwo Morpol, Lublin.

Chodubski A. (2004), Tożsamość lokalna a rozwój samorzq̨du terytorialnego, w: Samorzqd ponadgminny w Polsce - tradycja, odrodzenie, doświadczenie, red. B. Nawrot, J. Pokładecki, Wydawnictwo Naukowe Instytutu Nauk Politycznych i Dziennikarstwa Uniwersytetu im. Adama Mickiewicza, Poznań.

Chodubski A. (2006), Idea wybieralności władz w warunkach unifikacji świata, w: Zachowania wyborcze społeczeństwa polskiego po roku 1989. Próba ogladu zjawiska, red. A. Kasińska-Metryka, Wydawnictwo Akademii Świętokrzyskiej im. Jana Kochanowskiego, Kielce.

Drzonek M. (2013a), Reelekcje prezydentów miast $w$ wyborach bezpośrednich w Polsce, Dante, Kraków.

Drzonek M. (2013b), Zdobywanie władzy w mieście - efektywność strategii „,wiecznego prezydenta”, „Management and Business Administration. Central Europe”, nr 1.

Drzonek M. (2013c), Bezpartyjnie czy partyjnie? Efektywność wyborcza prezydentów polskich miast, Analizy Nowej Politologii, http://www.nowapolitologia.pl/politologia/marketing-polityczny/ bezpartyjnie-czy-partyjnie-efektywnosc-wyborcza-prezydentow-polskich-miast, 28 I 2013.

Drzonek M. (2014), Partie $w$ masce niepartyjności - uwagi o komitetach niby-bezpartyjnych $w$ elekcjach prezydentów miast, w: Partyjnie czy bezpartyjnie? Szkice o zdobywaniu władzy lokalnej, red. M. Drzonek, Wydawnictwo Naukowe Uniwersytetu Szczecińskiego, Szczecin.

Duverger M. (1973), Les partis politiques, Librairie Armand Colin, Paris.

Gendźwiłł A. (2010), Bezpartyjni prezydenci miast i ich znaczenie dla lokalnej polityki, „Studia Regionalne i Lokalne", nr 2.

Hess A. (2010), Mediatyzacja lokalnej komunikacji politycznej i strategie partyjne w kontekście samorzadowych kampanii wyborczych, w: Profesjonalizacja i mediatyzacja kampanii politycznych w Polsce, red. K. Churska-Nowak, S. Drobczyński, Wyższa Szkoła Nauk Humanistycznych i Dziennikarstwa, Poznań.

Heywood A. (2006), Politologia, PWN, Warszawa.

Kolczyński M., Faracik-Nowak M. (2013), Samorzqdność a przynależność partyjna, „Preferencje Polityczne", nr 7.

Matyja R. (2013), Rywalizacja polityczna w Polsce, Ośrodek Myśli Politycznej, Wyższa Szkoła Informatyki i Zarządzania, Kraków-Rzeszów.

Matyja R. (2014), Miasta w wyborach lat 1990-2011. Komunikat z badań, Ośrodek Studiów o Mieście, bmw.

Piasecki A. K. (2007), Czy wójtowi potrzebny jest marketing polityczny? Teoria i praktyka zastosowania marketingu przez liderów lokalnych wspólnot, w: Marketing polityczny, Szansa czy za- 
grożenie dla wspótczesnej demokracji?, red. P. Pawełczyk, Wydawnictwo Naukowe Instytutu Nauk Politycznych i Dziennikarstwa Uniwersytetu im. Adama Mickiewicza, Poznań.

Sartori G. (1976), Parties and Party Systems, Cambridge University Press, Cambridge.

Sartori G. (1994), Teoria demokracji, PWN, Warszawa.

Sobociński A. W. (1995), Samorzqd a demokracja, „Teoria i Praktyka Polityki. Materiały i Studia”, nr 1.

Sobolewska-Myślik K. (2008), Partie polityczne na poziomie lokalnym, w: Polityka lokalna. Właściwości, determinanty, podmioty, red. E. Ganowicz, L. Rubisz, Wydawnictwo Adam Marszałek, Toruń.

Ustawa z dnia 5 I 2011 r. Kodeks wyborczy, Dz. U. 2011, Nr 21, poz. 113 z późn. zm.

Wojtasik W. (2012), Funkcje wyborów w III RP, Wydawnictwo Uniwersytetu Śląskiego, Katowice.

Wojtasik W. (2013), Wyborcza selekcja elit politycznych w Polsce, „Athenaeum. Polskie Studia Politologiczne", nr 38.

\section{Multiple terms in office without political party affiliation? Remarks following the Re-election of 'everlasting mayors' in 2014}

\section{Summary}

Since 2002, town mayors in Poland have been elected in direct elections every four years. In thirty towns with county rights the same persons were elected in the years 2002-2010. They are named 'everlasting mayors' (multi-term mayors, incumbents). In the 2014 local elections three of them resigned from the campaign for re-election, ten 'everlasting mayors' lost the elections and seventeen of them won the elections once again. Their successes provide the starting point for determining the position of political parties and nonpartisan committees on local political scenes. The assumption is made that the political position of parties is powerful if the 'everlasting mayor' is effective in trying to gain re-election while formally representing this party on the local political scene. And conversely - parties have a weaker political position on the local political scene when the incumbent prefers to lead a nonpartisan election committee in the rivalry for re-election (an electoral committee of voters, or an electoral committee of a nongovernmental local organization). The final conclusion of the analysis is the following: in the 2014 local elections in Poland most of the 'multi-term mayors' were re-elected as representatives of nonpartisan committees. Only in two cities (Gdańsk, Świnoujście) were mayors' seats won by party political incumbents.

Key words: local politics, mayor of town elections, multi-term mayors, local power 
